\section{Field performance of poplar for bioenergy in southern Europe after two coppicing rotations: effects of clone and planting density}

\author{
Giovanni Di Matteo $^{(1)}$, Giulio Sperandio ${ }^{(2)}$, Stefano Verani ${ }^{(1)}$
}

Short Rotation Forestry (SRF) plantations are estimated around 7000 hectares in Italy, mostly established in northern regions. Recently thousands hectares of SRF were established in central and southern regions of Italy also (especially in Latium and Molise) due to the promising introduction of new clones resistant to summer water limiting and pest attacks. A poplar SRF plantation was established in central Italy in order to investigate the influence of site conditions and planting densities/spacings on the growth and yield production of three hybrid poplar clones (AF2, AF6 and Monviso). Cuttings of each clone were planted at two different densities/spacings and planting design as: (a) low density = 7140 cuttings ha $^{-1}$ in a single-row design (SR); (b) high density= 10360 cuttings ha ${ }^{-1}$ in a twin-rows design (TR). Growth (both diameter and height) and yield were evaluated after biennial (2006-2007) and triennial (2008-2010) rotation. Relationships between fresh weight and diameter were determined to calculate the yield of each clone expressed in $\mathrm{MgDM} \mathrm{ha}^{-1}$ years $^{-1}$. At the end of the triennial rotation (2010) all poplar clones showed very high stump survival rates with higher values in SR (89.9\%) compared to TR $(85.6 \%)$. AF2 clone can be advisable thanks to the higher yield production than both AF6 and Monviso. Considering planting densities/spacings, SR seems to be more advisable than TR in order to obtain a good biomass production and a low planting costs. Considering the coppicing cycles, triennial rotation allows higher annual yield production (average value of $13.0 \mathrm{MgDM} \mathrm{ha}^{-1}$ ) than biennial rotation (average: 10.1 $\mathrm{MgDM} \mathrm{ha}^{-1}$ ).

Keywords: Short Rotation Forestry, Hybrid Populus Clones, Coppicing Cycles, Yield, Growth, Optimal Density

\section{Introduction}

The international discussion on the climate change and the hypothesis that it is determined also by the human activities fosters the renewable energy uses. Renewable energy uses play a key role to honor the commitments that Italy has signed with the European Commission in order to achieve by 2020 for the whole Europe: (i) a reduction of $20 \%$ in energy consumption; (ii) a reduction of $20 \%$ in $\mathrm{CO}_{2}$ emission compared to 1990 ; (iii) more than $20 \%$ of the total energy demand will come from renewable energy. The Short Rotation Forestry (SRF) is one of the measures indicated by the article 3.4 (additional activities) of the Kyoto Protocol (Schulze et al. 2002); they serve as feedstock for the pulp and paper industry but also can be established specifically to address the feedstock needs for energy or biofuel industry and to combat desertification processes. Among these, the woody biomass attracts great attention as a renewable energy and as alternative to fossil fuels (e.g., firewood, wood chips and pellets). The wood biomass production for energy has promising productive and environmental benefits, with a minor impact on food markets, and a significant potential to lower net $\mathrm{CO}_{2}$ emissions in the environment and improving the energy balance (Smith 1995, IPCC 2007, Muller 2009). SRF system is an intensive cultivation: the fast-growing hardwoods at high density are employed and the average period of rotation is less than 10 years (Rockwood et al. 2004). The Italian interest of SRF as a renewable energy began in the 1990 s. Based on recent inventories (Bisoffi et al. 2008, Verani et al. 2009), the Italian surface of SRF was estimated around 7000 hectares, mostly established in northern Italy, where the regional services of Lombardy, Veneto, Piedmont and Friuli released goods grants to establish and manage the SRF. Also European actions aimed to promote and extend the SRF since 2005 (Biomass Action Plan). Poplars (Populus spp.), especially modern hybrids, are well adapted to site conditions in Italy, and are the most common tree species used in SRF planta-
(1) Consiglio per la Ricerca e la Sperimentazione in Agricoltura, Unità di ricerca per le Produzioni Legnose fuori Foresta (CRA-PLF), v. Valle della Quistione 27, I-00166 Rome (Italy); (2) Consiglio per la Ricerca e la Sperimentazione in Agricoltura, Unità di ricerca per l'Ingegneria Agraria (CRA-ING), v. della Pascolare 16, I-00015 Monterotondo (RM - Italy)

@ Giovanni Di Matteo

(giovanni.dimatteo@entecra.it)

Received: Jan 24, 2012 - Accepted: Aug 20, 2012

Citation: Di Matteo G, Sperandio GG, Verani $S, 2012$. Field performance of poplar for bioenergy in southern Europe after two coppicing rotations: effects of clone and planting density. iForest 5: 224-229 [online 2012-10-02] URL:

http://www.sisef.it/iforest/contents? id $=$ ifor $0628-005$

Communicated by: Renzo Motta

tions (Paris et al. 2011) because they show great plasticity over a wide range of habitats. However, most regions in central Italy are affected by long summer dryness, resulting to be a suboptimal site for poplar cultivation, due to the very high water consumption of the woody crop in comparison with northern latitudes. For this reason some poplar clones were selected for growing in suboptimal sites of Italy.

Other species for SRF, such as willow (Salix spp.), black locust (Robinia pseudoacacia L.) and eucalyptus (Eucalyptus spp.) are still under research assessment and are not commercially available yet (Scarascia-Mugnozza et al. 2007). This was because Robinia is strongly sensitive to water limiting; eucalypts are particularly sensitive to low winter temperatures; willows are also sensitive to water limitations. Indeed, they are currently used in others European country like Sweden (Mola-Yudegoa \& Aronssonb 2008), Hungary (Rédei 1998) and Portugal (Reed et al. 2003).

The SRF, owing to the high density and competition, grows with water and light limitations, associated with susceptibility to pest attacks (Giorcelli et al. 2010). Hence, SRF plantations should be planted on "optimal sites", with the support of "optimal cultural practices" to have higher productivity. Choosing the best planting density/spacing resulted to be a key-decision to ensure high production and high survival over time. This was because SRF plantations are characterized by continuous growth after their cutting, providing a living inventory of available biomass. Generally, harvesting of a 
SRF is carried out every two years (biennial rotation) over 5-6 coppicing rotations in order to obtain about $10-12 \mathrm{Mg} \mathrm{ha}^{-1}$ year $^{-1}$ of dry above-ground biomass (Armstrong et al. 1999, Pontailler et al. 1999, Benetka et al. 2002, Facciotto et al. 2006, Di Muzio Pasta et al. 2007, Verani \& Sperandio 2008, Fara et al. 2009). Several experiments have obtained new or already-in-use clones for biomass production (Mau \& Impens 1989, Baratto et al. 2008, Trnka et al. 2008). Hence, the biennial and annual yield of SRF has been extensively assessed by several studies (Minotta \& Muzzi 2007, Spinelli et al. 2008 Pannacci et al. 2009), many of which have focused on clonal poplar experiments, aimed at testing the productivity and pests resilience (Filat et al. 2010) under contrasting latitudinal sites and experimental trials (Kauter et al. 2003, Mareschi et al. 2005, Paris et al. 2011), but few studies have continuously monitored the growth of a SRF during its vegetative cycle.

The general objective of this work is the assessment of productive characteristics of three selected poplar clones (AF2, AF6 and Monviso) to site conditions of central Italy, as affected by the rotation cycles, as well as by the planting density, comparing low(7 140 cuttings ha $\left.^{-1}\right) v s$. high-density (10 360 cuttings ha ${ }^{-1}$ ) plantations.

\section{Materials and methods}

Site descriptions, plant material and experiment layout

The experimental plantation (total surface: 4 ha) was established in 2005 within the farm of the Agricultural Engineering Research Unit of the Agricultural Research Council (CRA-ING), $30 \mathrm{~km}$ east of Rome (Monterotondo; $42^{\circ} 06^{\prime} \mathrm{N}, 12^{\circ} 37^{\prime} \mathrm{E}$ ), on a flat field, with a clay-loam soil texture and a low level of soil organic matter, nitrogen and phosphorus (Colorio et al. 1996). Both preand post-planting agronomic practices are shown in Tab. 1, according to the recommended management practices in Italy (Facciotto 1998). The plantation was only irrigated with an emergency-irrigation in July $2005\left(1400 \mathrm{~m}^{3}\right)$ to promote a better rooting of cuttings. Cuttings had a length between 220 and $280 \mathrm{~mm}$ with a maximum diameter of $28 \mathrm{~mm}$. In order to favor the coppice's growth, a "cut back" at the end of the first vegetative season (2005) was carried out. At this date the average yield of the plantation was $1.9 \mathrm{MgDM} \mathrm{ha}^{-1}$.

Meteorological data (average annual temperature and annual precipitation) were collected from a nearby station, located few meters from the plantation. These data were calculated over the five observed years (from 2006 to 2010) and compared with the last ten years (from 2001 to 2010 - Tab. 2). Annual precipitation reached a maximum of
Tab. 1 - Main agronomic practices in the studied plantation.

Proceding crop
Plowing deep $(\mathrm{cm})$
Fertilization $\left(\mathrm{kg} \mathrm{ha}^{-1}\right)$
Harrowing deep $(\mathrm{cm})$
Planting date
Chemical weed control
Top dressing $\left(\mathrm{kg} \mathrm{ha}^{-1}\right)$
Irrigation $\left(\mathrm{m}^{3} \mathrm{ha}^{-1}\right)$
Cut-back date
Harvesting date

$927.2 \mathrm{~mm}$ for the year 2009 and a minimum of $473.0 \mathrm{~mm}$ for the year 2007. May-August precipitation values were similar among years (except 2007), with a mean value of the last 10 years of $42.3 \mathrm{~mm}$. Average annual temperature during the study period was $15.7^{\circ} \mathrm{C}$, whereas for the same period the average monthly temperature for July was $25.4^{\circ} \mathrm{C}$, with a mean value of the last 10 years of $15.3^{\circ} \mathrm{C}$. Drought period was shorter in the years 2008-2010 (3.5 months) than in years 2006-2009 (5 months).

Three poplar clones were evaluated: $P . \mathrm{x}$ canadensis Moench "AF2", $P$. nigra L. x $P$. x generosa A. Henry "AF6", $P$. x generosa A. Henry x $P$. nigra L. "Monviso" (Picco et al. 2007). They are the most trade between those selected for biomass production and for their resistance to natural infections of Melampsora spp. and Marssonina brunnea. To test the influence on growth of density/ spacing, the plantation was established with two different planting designs, differing in densities and spacings, both as single and twin rows, hereafter called "SR" and "TR", respectively; (i) low density (7 140 cuttings $\left.\mathrm{ha}^{-1}\right)$ were placed in a SR $(2.80 \mathrm{~m}$ between the rows and $0.50 \mathrm{~m}$ along the row); (ii) high density (10 360 cuttings ha $^{-1}$ ) were placed in a TR $(2.80 \mathrm{~m}$ between twin-rows, $0.75 \mathrm{~m}$ between the row forming a pair, $0.50 \mathrm{~m}$ along the rows).

The experimental data were recorded from 2007 to 2010 , in order to test two experimental treatments (factors): (i) two planting densities/spacings (main plot); and (ii) three clones (sub-plot). Each clone of SR was re- plicated six times on elemental plots (18 plots totally) with a unit surface area of 67.2 $\mathrm{m}^{2}$. In the TR, each clone was replicated four times (12 plots totally) with a unit surface area of $57 \mathrm{~m}^{2}$. The size of SR and TR plots were respectively $8.4 \mathrm{~m} \times 8 \mathrm{~m}$ (three rows and 16 stumps per row) and $7.1 \mathrm{~m} \mathrm{x} 8 \mathrm{~m}$ (two twin-rows and 32 stumps per row).

\section{Field performance measurements (growth and yield)}

Field performance was evaluated yearly by measuring the diameter at breast height (DBH) of all shoots in each replicated plot. Total height $(\mathrm{H})$ was measured on thirty shoots for each clone, in each replicated plot. A tree caliper (Silvanus type 1208, accuracy $0.5 \mathrm{~cm}$ ) was used for measuring the DBH and a logger's tape for determining tree height after felling.

In order to assess the yields for each clone, allometric relationships between fresh weight and DBH were determined in both SR and TR using non-linear regressions according to Al Afas et al. (2008) and Verani $\&$ Sperandio (2008) as follows (eqn. 1):

$$
Y=a x^{z}
$$

where $Y$ is the fresh weight of shoot $(\mathrm{kg}), x$ is the DBH $(\mathrm{cm})$ and $a$ and $z$ are the regression parameter to be determined. To estimate the parameters $a$ and $z$, a destructive sampling of 180 living trees $(30$ shoots $\times 3$ clones $\times 2$ density) was made. To obtain the dry weight from fresh weight, the moisture content on 45 shoots (15 per clone) was determined.
Tab. 2 - Summary of main meteorological characteristics during the study period (20062010) and for the last ten years (2001-2010). Data and metadata of PET (potential evapotranspiration for Monterotondo site) were extrapolated from the database of the Research Unit for Climatology and Meteorology applied to Agriculture (CRA-CMA). Source: $\mathrm{http} / / /$ old.politicheagricole.it/ucea/forniture/index $3 . \mathrm{htm}$

\begin{tabular}{ccccccc}
\hline Year & $\begin{array}{c}\text { Annual } \\
\text { Rainfall } \\
(\mathbf{m m})\end{array}$ & $\begin{array}{c}\text { Rainfall } \\
\text { May-August } \\
(\mathbf{m m})\end{array}$ & $\begin{array}{c}\text { PET } \\
(\mathbf{m m})\end{array}$ & $\begin{array}{c}\text { Aridity } \\
\text { Index } \\
(\mathbf{P} / \mathbf{P E T})\end{array}$ & $\begin{array}{c}\text { Average } \\
\text { Annual Temp } \\
\left({ }^{\circ} \mathbf{C}\right)\end{array}$ & $\begin{array}{c}\text { Average } \\
\text { Temp July } \\
\left({ }^{\circ} \mathbf{C}\right)\end{array}$ \\
\hline 2006 & 512.6 & 30.3 & - & - & 15.8 & 27.2 \\
2007 & 473 & 18.5 & - & - & 16.5 & 25 \\
2008 & 780.5 & 49.5 & - & - & 15.5 & 24.5 \\
2009 & 927.2 & 65.4 & - & - & 15.6 & 24.5 \\
2010 & 905.3 & 75.4 & - & - & 15 & 25.7 \\
$2001-2010$ & 627.5 & 42.3 & 1010 & 0.62 & 15.3 & 25.4 \\
\hline
\end{tabular}


Tab. 3 - Relationships between fresh weight and DBH for each clone and planting design observed at the end of the two coppicing rotations.

\begin{tabular}{cccccccc}
\hline \multirow{2}{*}{$\begin{array}{c}\text { Planting } \\
\text { Design }\end{array}$} & \multirow{2}{*}{ Clone } & \multicolumn{3}{c}{$\mathbf{2 0 0 7}(\mathbf{R 3 S 2})$} & \multicolumn{3}{c}{$\mathbf{2 0 1 0}(\mathbf{R 6 S 3})$} \\
\cline { 3 - 8 } & & $\mathbf{a}$ & $\mathbf{z}$ & $\mathbf{R}^{\mathbf{2}}$ & $\mathbf{a}$ & $\mathbf{z}$ & $\mathbf{R}^{\mathbf{2}}$ \\
\hline SR - & AF2 & 0.252 & 1.94 & 0.84 & 0.363 & 1.92 & 0.93 \\
Low density & AF6 & 0.17 & 2.25 & 0.84 & 0.302 & 2.09 & 0.96 \\
& Monviso & 0.136 & 2.52 & 0.96 & 0.327 & 1.98 & 0.92 \\
\hline TR - & AF2 & 0.218 & 2.01 & 0.92 & 0.451 & 1.69 & 0.94 \\
High density & AF6 & 0.188 & 2.19 & 0.63 & 0.488 & 1.81 & 0.94 \\
& Monviso & 0.335 & 1.84 & 0.9 & 0.939 & 1.21 & 0.92 \\
\hline
\end{tabular}

Tab. 4 - Main effect of experimental treatment on both growth and yield at the end of the biennial rotation (R3S2). Means in vertical sequence not followed by the same letter are significantly different at $\mathrm{P}=0.05$, according to Tukey's HSD test. (ns): not significant; $(*)$ : $\mathrm{P}=$ $0.05 ;(* *): \mathrm{P}=0.01 ;(* * *): \mathrm{P}=0.001$.

\begin{tabular}{|c|c|c|c|c|c|c|}
\hline \multirow[b]{2}{*}{ Treatment } & \multicolumn{6}{|c|}{ Growth year 2007 (R3S2) } \\
\hline & $\begin{array}{c}\text { DBH } \\
\text { cm }\end{array}$ & $\begin{array}{c}\text { Height } \\
\text { m }\end{array}$ & $\begin{array}{c}\text { Shoots } \\
\text { plant ha }{ }^{-1}\end{array}$ & $\begin{array}{l}\text { Shoots/ } \\
\text { Stump }\end{array}$ & $\begin{array}{c}\text { Survival } \\
\%\end{array}$ & $\begin{array}{c}\text { Yield } \\
\operatorname{Mg~ha}^{-1} \mathbf{y}^{-1}\end{array}$ \\
\hline AF2 & $2.6^{\mathrm{a}}$ & $4.8^{\mathrm{a}}$ & $28552^{a}$ & $3.6^{\mathrm{a}}$ & $92.2^{\mathrm{a}}$ & $11^{\mathrm{a}}$ \\
\hline AF6 & $2.7^{\mathrm{a}}$ & $4.6^{\mathrm{a}}$ & $28197^{\mathrm{a}}$ & $3.8^{\text {a }}$ & $90.6^{\mathrm{a}}$ & $10.8^{\mathrm{a}}$ \\
\hline Monviso & $2.7^{\mathrm{a}}$ & $5.3^{\mathrm{b}}$ & $21780^{b}$ & $2.9^{\mathrm{a}}$ & $92.5^{\mathrm{a}}$ & $8.8^{\mathrm{b}}$ \\
\hline TR - High density & 2.9 & 2.7 & 24214 & 2.6 & 89.3 & 11.8 \\
\hline SR - Low density & 2.4 & 4.8 & 28180 & 4.2 & 94.2 & 8.5 \\
\hline Average & 2.7 & 4.9 & 26176 & 3.4 & 91.7 & 10.1 \\
\hline Clone & ns & $* * *$ & $* *$ & ns & ns & $*$ \\
\hline Density & ns & ns & $* *$ & $* *$ & $*$ & $* *$ \\
\hline Clone $\mathrm{x}$ Density & ns & $* *$ & $* *$ & ns & ns & $* * *$ \\
\hline
\end{tabular}

Shoot fresh weight was measured on woody disks taken from basal, middle and upper parts of the stem just before each coppicing cycle. Woody disks were immediately weighed in the field with a precision scale (Orma model BC16D) and then taken into the laboratory for moisture determinations, according to the thermo-gravimetric methods (UNI ISO 3130 1985, UNI 9091 1987). The results of non-linear regressions between fresh weight and DBH are reported in Tab. 3. Except the clone AF6 of TR in 2007 (R3S2), observed coefficients of determination $\left(\mathrm{R}^{2}\right)$ from regression analysis were always larger than 0.8. Yield (expressed in
MgDM ha ${ }^{-1}$ ) of each clone was obtained by multiplying the estimated weight (using the specific allometric equation) of each single shoot for the number of the shoots per hectare.

Field performance in the following growing stages was evaluated as: roots aged 3 years and stems aged 2 years (R3S2, year 2007 just before the first harvesting); roots aged 4 years and stem aged 1 year (R4S1, vegetative season 2008); roots aged 5 years and stems aged 2 years (R5S2, vegetative season 2009); roots aged 6 years and stems aged 3 years (R6S3, vegetative season 2010 just before the second harvesting).

\section{Statistical analysis}

Data collected on DBH, H, yield, number of shoots ha $^{-1}$ and shoots/stump ratio were compared among clones and analyzed by two-way ANOVA in each separate year using PRISM software version 4.01 (GraphPad Software, Inc. San Diego, CA, USA). Measurements on individual trees were used as observations, whereas densities (2 levels) and clones (3 levels) were defined as factors. When significant differences $(\alpha=0.05)$ between means were detected, post-hoc tests were performed using Tukey HSD test for determining significance. Pairwise Student's $t$-test was used to test differences in wood moisture content between R3S2 and R6S3.

\section{Results}

\section{Effect of clone on growth and yield}

Variability among clones was observed in most of the studied parameters in R3S2, R4S1, R5S2 and R6S3 respectively (Tab. 4 and Tab. 5). Apart R3S2 where non-significant differences in DBH and stool survival were detected, AF2 clone usually has always shown a better growth performance compared to AF6 and Monviso clones. Yield interactions between density and clone were significant in both R3S2 and R6S3 and reflected the much greater increases for TR in R3S2 and for clone AF2 in R6S3.

Considering that the moisture content observed in R3S2 and R6S3 showed non-significant differences among clones and among densities with an average value of $54.2 \%$ (Tab. 6), yields obtained from both R3S2 and R6S3 showed significant differences among clones $(\mathrm{P}<0.05$ for both). This was because AF2 clone gave the highest mean yield (11.0 MgDM ha $\left.\mathrm{Mear}^{-1}\right)$, whereas Monviso the lowest mean yield (8.8 MgDM ha $^{-1}$ year $^{-1}$ ) in R3S2. Similarly, yield of AF2 clone also reached highest mean values in R6S3 (13.9 MgDM ha . $^{-1}$ year $^{-1}$ ) compared to both AF6 and Monviso clones (13.2 and 12.0 $\mathrm{MgDM} \mathrm{ha}^{-1}$ year $^{-1}$ respectively). This was because at the end of the triennial rota-

Tab. 5 - Main effect of experimental treatment on both growth and yield at the end of the triennial rotation (R6S3). Means in vertical sequence not followed by the same letter are significantly different at $\mathrm{P}=0.05$ according to Tukey's HSD test. (ns): not significant; $(*)$ : $\mathrm{P}=$ $0.05 ;(* *): \mathrm{P}=0.01 ;(* * *): \mathrm{P}=0.001$.

\begin{tabular}{|c|c|c|c|c|c|c|c|c|c|c|}
\hline \multirow{3}{*}{ Treatment } & \multirow{2}{*}{\multicolumn{2}{|c|}{$\begin{array}{c}2008 \\
1^{\text {st }} \text { year }(\mathrm{R} 4 \mathrm{~S} 1)\end{array}$}} & \multirow{2}{*}{\multicolumn{2}{|c|}{$\begin{array}{c}2009 \\
2^{\text {nd }} \text { year }(\text { R5S2) } \\
\end{array}$}} & \multicolumn{6}{|c|}{2010} \\
\hline & & & & & & & $3^{\text {th }}$ ye & (R6S3) & & \\
\hline & $\begin{array}{c}\text { DBH } \\
\text { cm }\end{array}$ & $\begin{array}{l}\text { Height } \\
\text { m }\end{array}$ & $\begin{array}{c}\text { DBH } \\
\text { cm }\end{array}$ & $\begin{array}{l}\text { Height } \\
\text { m }\end{array}$ & $\begin{array}{c}\text { DBH } \\
\text { cm }\end{array}$ & $\begin{array}{c}\text { Height } \\
\text { m }\end{array}$ & $\begin{array}{c}\text { Shoot } \\
\text { plant } \text { ha }^{-1}\end{array}$ & $\begin{array}{l}\text { Shoot/ } \\
\text { Stump }\end{array}$ & $\begin{array}{c}\text { Survival } \\
\%\end{array}$ & $\begin{array}{c}\text { Yield } \\
\mathrm{Mg} \mathrm{ha}^{-1} \mathrm{y}^{-1}\end{array}$ \\
\hline $\mathrm{AF} 2$ & $1.8^{\mathrm{a}}$ & $3.7^{\mathrm{a}}$ & $2.6^{\mathrm{a}}$ & $6.7^{\mathrm{a}}$ & $3.3^{\mathrm{a}}$ & $6.7^{\mathrm{a}}$ & $27551^{\mathrm{a}}$ & $3.3^{\mathrm{a}}$ & $90.2^{\mathrm{a}}$ & $13.9^{\mathrm{a}}$ \\
\hline AF6 & $1.4^{\mathrm{b}}$ & $3.2^{\mathrm{b}}$ & $2.2^{\mathrm{b}}$ & $6.0^{\mathrm{b}}$ & $3.1^{\mathrm{a}}$ & $5.7^{\mathrm{b}}$ & $25612^{c}$ & $3.4^{\mathrm{a}}$ & $84.3^{b}$ & $13.2^{\mathrm{a}}$ \\
\hline Monviso & $1.5^{\mathrm{b}}$ & $3.3^{\mathrm{b}}$ & $2.0^{\mathrm{b}}$ & $6.4^{\mathrm{a}}$ & $2.8^{\mathrm{b}}$ & $6.7^{\mathrm{a}}$ & $26639^{b}$ & $3.5^{\mathrm{a}}$ & $88.9^{a}$ & $12.0^{\mathrm{b}}$ \\
\hline TR- High density & 1.5 & 3.4 & 1.9 & 5.7 & 2.7 & 6.2 & 28840 & 3.0 & 85.6 & 12.2 \\
\hline SR - Low density & 1.6 & 3.4 & 2.3 & 6.3 & 3.4 & 6.6 & 24361 & 3.8 & 89.9 & 13.9 \\
\hline Average & 1.5 & 3.4 & 2.1 & 6.0 & 3.1 & 6.4 & 26601 & 3.4 & 87.8 & 13.0 \\
\hline Clone & $* * *$ & $* * *$ & $* * *$ & $* * *$ & $* *$ & $* *$ & $*$ & ns & $*$ & $*$ \\
\hline Density & ns & ns & $* *$ & $* * *$ & $* *$ & ns & $* *$ & ns & $*$ & $*$ \\
\hline Clone x Density & $* *$ & ns & ns & $* *$ & ns & $* *$ & $* *$ & ns & $* *$ & $* *$ \\
\hline
\end{tabular}


Fig. 1 - Shoot DBH distribution among clones observed at the end of the two coppicing rotations (i.e., R3S2 and R6S3).

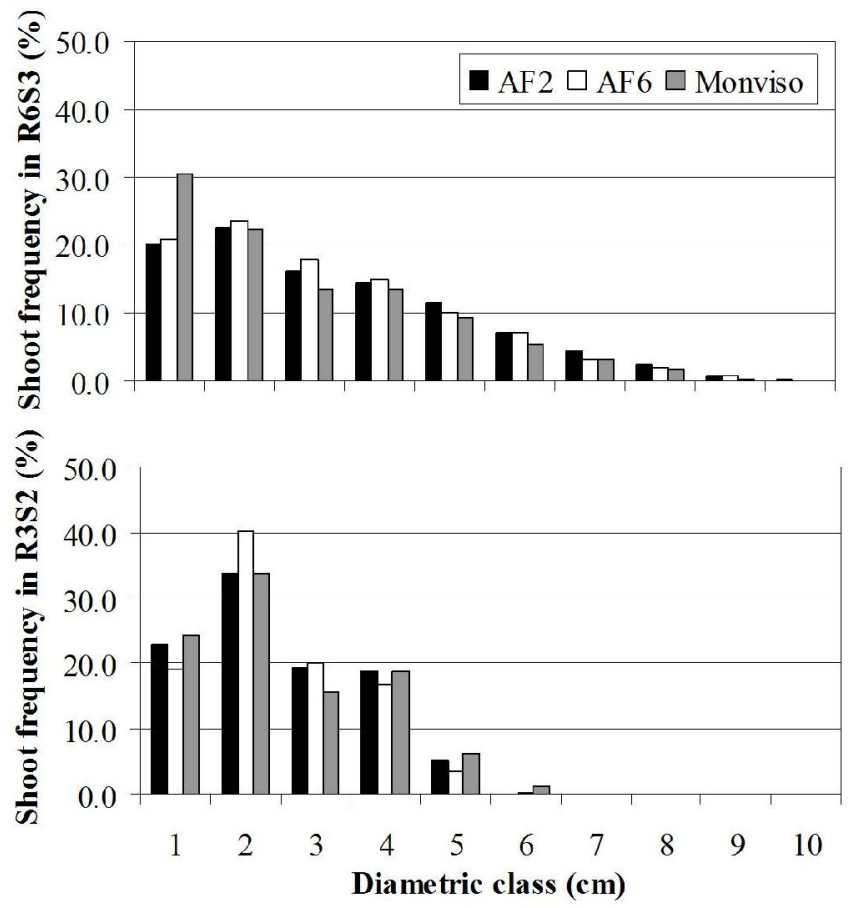

tion, AF2 showed both highest stump survival $(90.2 \%)$ compared to AF6 (84.3\%) and Monviso (88.8\%), and highest number of shoots $\left.\left(27751 \text { trees }^{-1}\right)^{-1}\right)$ compared to those of the other two clones (25 612 and 26183 shoots $\mathrm{ha}^{-1}$ for both AF6 and Monviso).

\section{Effect of density on growth and yield}

Density had significant effects on both growth and yield in R3S2, R5S2 and R6S3,

whereas non-significant differences were found in R4S1. In R3S2 we observed a density effect on shoots/stump ratio with highest values observed in SR compared to TR. At the end of the triennial rotation (R6S3) the SR showed higher yield (13.9 $\mathrm{MgDM} \mathrm{ha}^{-1}$ year $^{-1}$ ) compared to TR (12.2 $\mathrm{MgDM} \mathrm{ha}^{-1}$ year $\left.{ }^{-1}\right)$. Conversely, at the end of the biennial rotation (R3S2) the highest yield was obtained in TR (11.8 MgDM ha ${ }^{-1}$ year $\left.^{-1}\right)$ com-

Fig. 2 - Shoot DBH distribution among planting designs observed at the end of the two coppicing rotations (i.e., $\mathrm{R} 3 \mathrm{~S} 2$ and R6S3)
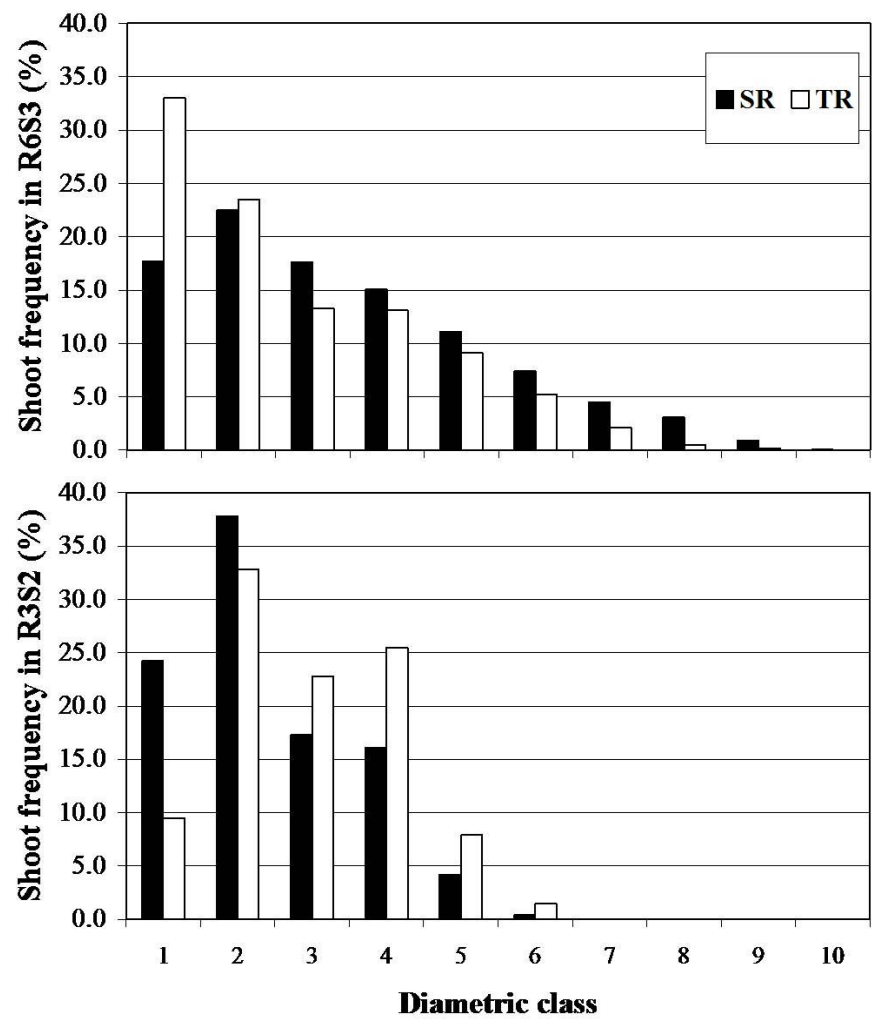

Tab. 6 - Moisture content observed in R3S2 and R6S3.

\begin{tabular}{lcc}
\hline $\begin{array}{l}\text { Moisture } \\
\text { content \% }\end{array}$ & $\begin{array}{c}\mathbf{2 0 0 7} \\
\text { (R3S2) }\end{array}$ & $\begin{array}{c}\mathbf{2 0 1 0} \\
\text { (R6S3) }\end{array}$ \\
\hline AF2 & 52.41 & 55.96 \\
AF6 & 53.01 & 55.62 \\
Monviso & 53.63 & 54.62 \\
\hline
\end{tabular}

pared to SR (8.5 MgDM ha $\left.\mathrm{Mear}^{-1}\right)$. Density effect on growth (DBH and $\mathrm{H}$ ) was time dependent as indicated by two different growth phases. The first phase was characterized by the absence of a density effect, which lasted 2 years (i.e., R3S2 and R4S1). Conversely, the second phase was characterized by an increase in R5S2 and R6S3. This could be explained by the fact that TR showed lowest values in growth, due to the intra-specific competition more prolonged in $\mathrm{R} 5 \mathrm{~S} 2$ and R6S3 than in R4S1. DBH increased predictably as density between trees decreased, as already reported (Alcorn et al. 2007), especially for the triennial rotation. Interestingly, total height $(\mathrm{H})$ increases as density decreased for both coppicing rotations. Variations in height growth with changes in available growing space could be attributed to ontogeny, to the range of tested spacing treatments, or to species. This was because height growth plays an important role in morphological acclimation to light competition (Lanner 1985), with plants tending to allocate more photosynthate to height than diameter growth, which results in increasing stem slenderness. Moreover we observed a change in distribution among diametric classes of the shoot populations according to the two harvesting date at the end of the first (R3S2) and second coppicing rotation (R6S3). This was because there was a shift towards higher frequencies in the lower diametric classes in R6S3 (Fig. 1), such as for shoots of the first two diametric classes of TR (Fig. 2), with negative consequences on qualitative characteristics of the woody biomass, likely due to an higher bark percentage (Guidi et al. 2008). This response could explain the occurrence of larger height growth in SR, and faster shifts vs. higher diametric classes in R6S3 and TR, highlighting a different trade-off between mechanical stability of the stem and height growth.

\section{Discussion}

Poplar's cultivation for yield production in central and southern Italy is limited by spring and summer drought. Of course, even in optimal climatic locations, the SRF cultivation should be always accompanied by cultural operations, such as irrigation and fertilization, for improving soil fertility. Optimal conditions for hybrid poplars cultivation in Italy are: (i) mean annual temperature: 8.5 to $17{ }^{\circ} \mathrm{C}$; (ii) summer precipitation: 
100-150 mm. In our case-study, local climatic conditions were outside the optimum for poplars (aridity index of $0.62 \mathrm{~mm}$ ). Indeed, we observed very long summer drought (average 2006-2010: up to 4.0 months), and May-August precipitation always below 80 $\mathrm{mm}$, with an average value of the last ten years of $40.2 \mathrm{~mm}$. Therefore, the case-study is a sub optimal site for cultivation of poplar species. Yearly above-ground yields in SRF plantations for the same hybrid poplar clones planted in northern Italy (along the Po valley) are greater, ranging between 5.6 and 17.9 $\mathrm{MgDM} \mathrm{ha}^{-1}$ year $^{-1}$ (Paris et al. 2011) Nevertheless, the yearly yield obtained in the plantations in northern Italy are similar to those observed in boreal regions (central Europe, USA, and Canada) not affected by summer dryness (Armstrong et al. 1999, DeBell et al. 1996). Contrastingly, lower yearly productions were observed by Minotta \& Muzzi (2007) and Pannacci et al. (2009) in SRF plantations of central Italy, with yields ranging between 1.3 and $6.2 \mathrm{MgDM} \mathrm{ha}^{-1}$ year ${ }^{-1}$. The results obtained in this study are surprisingly similar to those reported for boreal (cold temperate) conditions, ranging between 10.1 (at the end of the first coppicing rotation) and 13.0 $\mathrm{MgDM} \mathrm{ha}^{-1}$ year $^{-1}$ (at the end of the second coppicing rotation). Christersson (2010) reported for Sweden an average yearly yields of 3-10 $\mathrm{MgDM} \mathrm{ha}^{-1}$ year $^{-1}$ in 5-year-old plantations, while Willebrand et al. (1993) reported average yearly yields varying between 8 and $14 \mathrm{MgDM}^{-1}$ year $^{-1}$ in 6-year-old plantations. In spite of the short duration of the growing season and low soil nitrogen in boreal regions, a yield of $20 \mathrm{MgDM} \mathrm{ha}^{-1}$ year ${ }^{-1}$ could easily be achieved in our plantation by adding fertilizers and selecting appropriate clones and spacings, as reported for Swedish plantations by Weih (2004). This in fact would explain the high potential of the studied poplar clones, even in Mediterranean sites affected by summer drought.

\section{Conclusion}

In southern Europe, the use of SRF plantations appears to offer a highly promising and politically desirable option among the range of renewable energy sources currently available. SRF has been adopted mostly in northern Italy owing of the favorable climatic and soil conditions for poplars cultivation. Demand for woody biomass for fuel, energy purposes or fiber combined with reduced land availability has forced land managers to increase productivity of SRF plantations. Under such circumstances new high-yielding poplar clones were tested for growing in areas of central Italy affected by Mediterranean climatic conditions. Our study has shown that the climate of central Italy offers favorable conditions for the biomass production of selected hybrid poplar clones, high- lighting very high productive potential when summer dry periods are frequent (especially from May to August) and temperatures are less mild (slightly higher than the normal).

The poplar clones tested had the best performances in terms of growth and yield when planted in a SR design during the second coppicing rotation. Therefore SR (7 140 cuttings ha ${ }^{-1}$ ) was more advisable than TR (10 360 cuttings ha $^{-1}$ ) in order to obtain good biomass production with low planting costs. At clone-level, AF2 showed higher $\mathrm{DBH}$ values and yield productions than AF6 and Monviso in both biennial (R3S2) and triennial (R6S3) rotations.

Significant functional relationships between fresh biomass production and $\mathrm{DBH}$, appropriate for this climatic area and environmental conditions, for every poplar clone were found. These may be used for a non-destructive prediction of dry yield and for rapid yield estimations of the shoot populations.

\section{Acknowledgments}

Funds for this study were provided by the Italian Ministry of Agriculture Food and Forest Politics (D.M. 487/7303/2004) within the COFEA project (Costituzione di una Filiera Energetica di Autoconsumo) and developed within the post-doctoral research activities of Giovanni Di Matteo on biomass productions for energy purposes in Short Rotation Forestry of central Italy.

\section{References}

Al Afas N, Marron N, Van Dongen S, Laureysens I, Ceulemans R (2008). Dynamics of biomass production in a poplar coppice culture over three rotations (11 years). Forest Ecology and Management 255: 1883-1891. - doi: 10.1016/j.foreco .2007 .12 .010

Alcorn PJ, Pyttel P, Bauhus J, Smith RGB, Thomas D, James R, Nicotra A (2007). Effects of initial planting density on branch development in 4-year-old plantation grown Eucalyptus pilularis and Eucalyptus cloeziana trees. Forest Ecology and Management 252: 41-51. - doi: 10.1016 /j.foreco.2007.06.021

Armstrong A, Johns C, Tubby I (1999). Effects of spacing and cutting cycle on the yield of poplar grown as an energy crop. Biomass and Bioenergy 17: 305-314. - doi: 10.1016/S0961-9534 (99)00054-9

Baratto G, Bergante S, Facciotto G, Annunziati M (2008). Studies of poplars and willows short rotation coppice establishment. In: $23^{\text {rd }}$ Session of International Poplar Commission "Poplar, Willow and People's Wellbeing". Beijing (China) 27-30 October 2008. Abstract of submitted papers, pp. 15.

Benetka V, Bartáková I, Mottl J (2002). Productivity of Populus nigra L. ssp. nigra under short-rotation culture in marginal areas. Biomass and Bioenergy 23 (5): 327-336. - doi: 10.1016/ S0961-9534(02)00065-X

Bisoffi S, Minotta G, Paris P (2008). Forest plan- tations and farm forestry in Italy: directions for cultivations and valorisations. In: Proceedings of the $3^{\text {rd }}$ "Silvicultural National Congress". Taormina (ME - Italy) 16-19 October 2008, pp. 729 736. [in Italian]

Christersson L (2010). Wood production potential in poplar plantations in Sweden. Biomass and Bioenergy 34 (9): 1289-1299. - doi: 10.1016/j.biombioe.2010.03.021

Colorio G, Beni C, Facciotto G, Allegro G, Frison $\mathrm{G}$ (1996). Influence of the cultural practices before planting on growth and phytosanitary status of poplar. Informatore Agrario 22: 51-57. [in Italian]

DeBell DS, Clendenen GW, Harrington CA, Zasada JC (1996). Tree growth and stand development in short-rotation Populus plantings: 7-year results for two clones at three spacings. Biomass and Bioenergy 11 (4): 253-269. - doi: 10.1016/ 0961-9534(96)00020-7

Di Muzio Pasta V, Negri M, Facciotto G, Bergante S, Maggiore TM (2007). Growth dynamics and biomass production of 12 poplar and 2 willow clones in a short rotation coppice in northern Italy. In: Proceedings of the " $15^{\text {th }}$ European Biomass Conference and Exhibition". Berlin (Germany) 7-11 May 2007, pp. 749-755.

Facciotto G (1998). Le lavorazioni del suolo in pioppicoltura. Sherwood 31: 39-44.

Facciotto G, Bergante S, Lioia C, Rosso L, Mughini G, Zenone T, Nervo G (2006). Yields of poplar and willow in short rotation forestry. Forest@ 3 (2): 238-252. - doi: 10.3832/ efor0374-0030238

Fara L, Filat M, Chira D, Fara S, Nutescu C (2009). Preliminary research on short rotation cycle poplar clones for bioenergy production. In: Proceedings of the International Conference "RIO 9: World Climate and Energy Event" (Krauter S, Baranowsky F, Blandon NR, Kempf E eds). Rio de Janeiro (Brazil) 17-19 March 2009, pp. 127-132.

Filat M, Chira D, Nica MS, M. Dogaru (2010). First year development of poplar clones in biomass short rotation coppiced experimental cultures. Annals of Forest Research 53 (2): 151160. [online] URL: http://www.editurasilvica.ro/ afr/53/2/filat.pdf

Giorcelli A, Allegro G, Verani S (2010). Phytosanitary concerns in the biomass poplar plantation of the COFEA Project (Monterotondo - Rome). In: IPC WP6 Working party, Workshop meeting "Environmental applications of poplar and willow". Montelibretti (RM - Italy) 17-18 September 2010 (poster session).

Guidi W, Piccioni E, Ginanni M, Bonari E (2008). Bark content estimation in poplar (Populus deltoites L.) short-rotation coppice in Central Italy. Biomass and Bioenergy 32: 518524. - doi: 10.1016/j.biombioe.2007.11.012

IPCC (2007). Summary for policy makers, contribution of working group II to the fourth assessment report of the Intergovernmental Panel on Climate Change (IPCC). [online] URL: http://www.ipcc-wg2.org/index.html

Kauter D, Lewandowski I, Claupein W (2003). 
Quantity and quality of harvestable biomass from Populus short rotation coppice for solid fuel use - a review of the physiological basis and management influences. Biomass and Bioenergy 24: 411-427. - doi: 10.1016/S0961-9534(02) 00177-0

Lanner RM (1985). On the insensitivity of height growth to spacing. Forest Ecology and Management 13: 143-148. - doi: 10.1016/0378-1127(85) 90030-1

Mareschi L, Paris P, Sabatti M, Nardin F, Giovanardi R, Manazzone S, Scarascia Mugnozza G (2005). New varieties of poplar for biomass provide interesting productivity. Informatore Agrario 18: 49-53. [in Italian]

Mau F, Impens I (1989). Comparative growth analysis of five first year establishment poplar clones (Populus sp) grown under short-rotation intensive culture system. Annales de Sciences Forestière 46: 250-255. - doi: 10.1051/forest: 19890559

Minotta G, Muzzi E (2007). Indagini su cedui di pioppo a turno breve nella pianura ferrarese. Italia Forestale e Montana 5: 411-419.

Mola-Yudegoa B, Aronssonb P (2008). Yield models for commercial willow biomass plantations in Sweden. Biomass and Bioenergy 32: 829-837. - doi: 10.1016/j.biombioe.2008.01.002 Muller A (2009). Sustainable agriculture and the production of biomass for energy use. Climatic Change 94: 319-331. - doi: 10.1007/s10584008-9501-2

Pannacci E, Bartolini S, Covarelli G (2009). Evaluation of four poplar clones in a short rotation forestry in Central Italy. Italian Journal of Agronomy 4: 191-198. - doi: 10.4081/ija.2009.4.191

Paris P, Mareschi L, Sabatti M, Pisanelli A, Ecosse A, Nardin F, Scarascia Mugnozza G (2011). Comparing hybrid Populus clones for
SRF across northern Italy after two biennial rotations: survival, growth and yield. Biomass and Bionergy 35: 1524-1532. - doi: 10.1016/j.biombioe.2010.12.050

Picco F, Giorcelli A, Castro G (2007). Dichotomous key for the nursery recognition of the main poplar clones grown in the European Union. Volume II Clonal cards. CRA-PLF, Research Units for Intensive Wood Production, Casale Monferrato, Italy, pp. 352.

Pontailler JY, Ceulemans R, Guittet J (1999). Biomass yield of poplar after five 2-year coppice rotations. Forestry 72 (2): 157-163.

Reed DD, Jones EA, Tomé M, Araùjo MC (2003). Models of potential height and diameter for $\mathrm{Eu}$ calyptus globulus in Portugal. Forest Ecology and Management 172: 191-198. - doi: 10.1016/ S0378-1127(01)00802-7

Rockwood DL, Naidu CV, Carter DR, Rahmani M, Spriggs TA, Lin C, Alker GR, Isebrands JG, Segrest SA (2004). Short-rotation woody crops and phytoremediation: opportunities for agroforestry? Agroforestry Systems 61: 51-63. - doi: 10.1023/B:AGFO.0000028989.72186.e6

Rédei K (1998). Black locust (Robinia pseudoacacia L.) growing in Hungary. Forest Research Institute, Budapest, Hungary, pp. 50.

Scarascia-Mugnozza G, Sabatti M, Paris P (2007). La produzione di biomassa da colture arboree: realtà italiana e prospettive. In "Nuove frontiere dell'arboricoltura italiana" (Silverio $\mathrm{S}$ ed). Gruppo Perdisa, Bologna, Italy, pp. 517-533.

Schulze ED, Valentini R, Sanz MJ (2002). The long way from Kyoto to Marrakesh: implication of the Kyoto Protocol negotiations for global ecology. Global Change Biology 8: 505-518. doi: 10.1046/j.1365-2486.2002.00523.x

Smith CT (1995). Environmental consequences of intensive harvesting. Biomass and Bioenergy 9:
161-179. - doi: 10.1016/0961-9534(95)00088-7 Spinelli R, Nati C, Magagnotti N (2008). Harvesting short rotation poplar plantation for biomass production. Croatian Journal of Forestry Engineering 29 (2): 129-139.

Trnka M, Trnka M, Fialova J, Koutecky V, Fajman M, Zalud Z, Hejduk S (2008). Biomass production and survival rates of selected poplar clones grown under a short-rotation system on arable land. Plant and Soil Environment 52: 7888. [online] URL: http://agriculturejournals.cz/ publicFiles/00740.pdf

UNI 9091 (1987). Wood - determination of moisture content - oven drying. Italian Organization for Standardization (UNI) Edition. [online] URL: http://engineers.ihs.com/document/abstract/JUJO KCAAAAAAAAAA

UNI ISO 3130 (1985). Wood - determination of moisture content for physical and mechanical tests. Italian Organization for Standardization (UNI) edition. [online] URL: http://engineers.ihs.com/document/abstract/UKDOKCAAAAAAA AAA

Verani S, Sperandio G (2008). Pioppeto da biomassa a rotazione biennale. Caratteristiche e produttività dei cloni. Sherwood 148: 39-42. Verani S, Sperandio G, Tarchi M (2009). Piantagioni dedicate da biomassa. Analisi GIS nella regione Lazio. Sherwood 157: 41-45.

Weih M (2004). Intensive short rotation forestry in boreal climates: present and future perspectives. Canadian Journal of Forest Research 34 (7): 1369-1378. - doi: 10.1139/x04-090 Willebrand E, Ledin S, Verwijst T (1993). Willow coppice systems in short rotation forestry: effects of plant spacing, rotation length and clonal composition on biomass production. Biomass and Bioenergy 4: 323-331. - doi: 10.1016/09619534(93)90048-9 